CZASOPISMO INŻYNIERII LĄDOWEJ, ŚRODOWISKA I ARCHITEKTURY JOURNAL OF CIVIL ENGINEERING, ENVIRONMENT AND ARCHITECTURE

JCEEA, t. XXXIV, z. 64 (1/17), styczeń-marzec 2017, s. 347-358, DOI:10.7862/rb.2017.32

\author{
Mariusz MAŚLAK ${ }^{1}$ \\ Michał PAZDANOWSKI ${ }^{2}$ \\ Janusz SIUDUT ${ }^{3}$
}

\title{
KSZTAŁTOWANIE ELEMENTÓW W MODERNIZOWANYCH STALOWYCH ZBIORNIKACH PALIWOWYCH WYNIKAJĄCE ZE ZMIAN UŻYTKOWYCH ORAZ WZRASTAJĄCYCH WYMAGAŃ ŚRODOWISKOWYCH
}

\begin{abstract}
Omówiono zmiany konstrukcyjne niezbędne do wykonania w użytkowanych stalowych zbiornikach paliwowych jeśli planuje się ich dalsze wykorzystywanie przy zmienionych warunkach eksploatacji. W szczególności rozważa się sposób modernizacji typowego naziemnego zbiornika cylindrycznego $\mathrm{z}$ dachem pływającym, taki aby przystosować go do magazynowania paliwa lotniczego typu JET. Zalecanym rozwiązaniem jest w tym przypadku nadbudowa lekkiej kopuły aluminiowej. Drugą kwestią jest doszczelnienie dotychczas stosowanej konstrukcji dna zbiornika, wymagane przez aktualnie obowiązujące przepisy środowiskowe. Można tego dokonać albo kształtując dodatkowe drugie dno, stalowe lub kompozytowe, z przestrzenią monitorującą, albo poprzez podniesienie zbiornika i zainstalowanie pod jego dnem nieprzepuszczalnej dla produktów naftowych geomembrany z systemem monitorowania nieszczelności.
\end{abstract}

Słowa kluczowe: zbiornik stalowy, modernizacja, sposób użytkowania, wymagania środowiskowe, kształtowanie elementów

\section{Wprowadzenie}

Obecnie w Polsce około 60\% stalowych zbiorników walcowych o osi pionowej spośród tych wykorzystywanych do magazynowania paliw płynnych stanowią obiekty wybudowane $\mathrm{w}$ latach siedemdziesiątych ubiegłego wieku, a zatem z prawie czterdziestoletnim okresem eksploatacji. Na ogół były one

${ }^{1}$ Autor do korespondencji / corresponding author: Mariusz Maślak, Politechnika Krakowska, ul. Warszawska 24, 31-155 Kraków, tel.: +48126415673, e-mail: mmaslak@pk.edu.pl

${ }^{2}$ Michał Pazdanowski, Politechnika Krakowska, ul. Warszawska 24, 31-155 Kraków, tel.: +48126282929, e-mail: michal@15.pk.edu.pl

3 Janusz Siudut, PKN Orlen S.A., Terminal Paliw numer 81, ul. Olszanicka 38a, 30-241 Kraków, tel.: + 48126365702, e-mail: janusz.siudut@ orlen.pl 
realizowane na podstawie typowego projektu technicznego [1], z przeznaczeniem do przechowywania produktów naftowych o dużej prężności par i ciężarze objętościowym $\rho \leq 9 \mathrm{kN} / \mathrm{m}^{3}$. Najczęściej są to zbiorniki naziemne, spawane, odpowiednio z dachem pływającym o pojemności $2000 \mathrm{~m}^{3}$ lub $5000 \mathrm{~m}^{3}$ albo $\mathrm{z}$ dachem stałym o pojemności $500 \mathrm{~m}^{3}$ lub $1000 \mathrm{~m}^{3}$. W chwili odbioru niewątpliwie spełniały one wszystkie ówczesne wymagania pozwalające na ich formalne dopuszczenie do użytkowania. Od tego czasu w przedsiębiorstwach zajmujących się magazynowaniem i dystrybucją paliw nastąpiły jednak istotne zmiany logistyczne. Zamknięto szereg nierentownych, stosunkowo małych baz paliwowych a w miejscach ich dużego „zagęszczenia” wytypowano bazy o charakterze jedynie magazynowym, specjalizujące się w przechowywaniu konkretnego rodzaju paliwa, na przykład oleju napędowego lub paliwa lotniczego typu JET. Wymusiło to konieczność modernizacji zbiorników w tego typu bazach, spowodowanej przede wszystkim zmianą sposobu użytkowania tych obiektów. Drugim istotnym czynnikiem generującym na tym polu potrzebę zastosowania nowych rozwiązań konstrukcyjnych było zaostrzenie wymagań środowiskowych związanych głównie z zapobieganiem lub co najmniej z efektywnym monitorowaniem ewentualnych wycieków magazynowanego paliwa. Trzeba zauważyć, że znaczna liczba użytkowanych przez wiele lat zbiorników paliwowych nie spełnia obecnie obowiązujących przepisów. Dotyczy to chociażby dopuszczalnych odchyłek pomierzonej w chwili badania stanu technicznego faktycznej geometrii ich płaszcza i dna od zakładanej w projekcie konfiguracji idealnej. Przykładowo, dla zbiornika o pojemności $5000 \mathrm{~m}^{3}$ i o średnicy wewnętrznej 24,62 m lokalne deformacje (to znaczy wybrzuszenia lub wklęśnięcia) środkowej części dna nie powinny przekraczać następujących wartości [2]:

- strzałka ugięcia płaszczyzny odkształconej - max $100 \mathrm{~mm}$,

- powierzchnia pojedynczej deformacji - około $5 \mathrm{~m}^{2}$,

- liczba istotnych deformacji na powierzchni dna - max 5.

Tymczasem rzeczywiste deformacje są często nie tylko znacząco większe ale i częściej inwentaryzowane. Przykład stosownego pomiaru odnoszącego się do typowego dna użytkowanego zbiornika pokazano na Rys. 1. Łatwo zauważyć, że:

- faktyczna strzałka ugięcia płaszczyzny odkształconej dochodziła do $140 \mathrm{~mm}$, - powierzchnię pojedynczej deformacji oszacowano na około $9 \mathrm{~m}^{2}$,

- liczba zinwentaryzowanych deformacji na powierzchni dna wynosiła 7.

Niewątpliwie, o stanie technicznym użytkowanego stalowego, naziemnego zbiornika paliwowego w głównej mierze decyduje stan zachowania żelbetowej konstrukcji jego fundamentu, a także stopień degradacji korozyjnej i deformacji blach dna, pasów płaszcza, dachu i schodów. Z tego względu każdą decyzję dotyczącą potencjalnej modernizacji rozpatrywanego zbiornika musi poprzedzić kompleksowa ekspertyza inwentaryzująca jego słabe punkty i oceniająca możliwość i zakres ewentualnego wykorzystania poszczególnych elementów konstrukcyjnych po zmianie dotychczasowego sposobu użytkowania. 


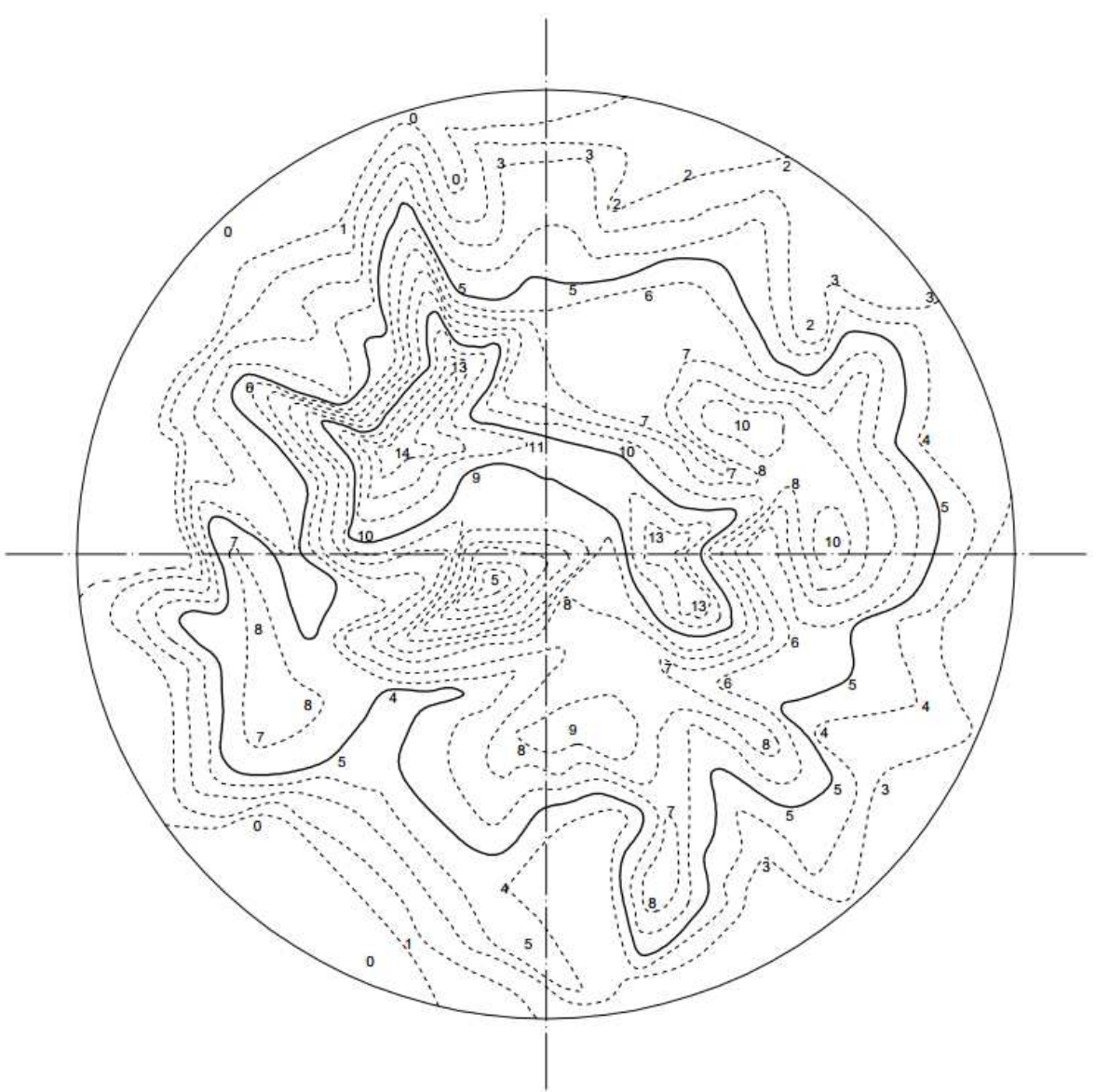

Rys. 1. Pomierzone deformacje blach dna typowego użytkowanego stalowego zbiornika paliwowego o pojemności $5000 \mathrm{~m}^{3}$. Wyniki podano w centymetrach, warstwice co $1 \mathrm{~cm}$

Fig. 1. Deformations measured for typical bottom sheets of the steel tank for fuel storage with a capacity of $5000 \mathrm{~m}^{3}$ being in-service. The results are given in centimeters, contour lines marked at $1 \mathrm{~cm}$ intervals

\section{Modernizacje wymuszone wymogiem zagwarantowania niezbędnej szczelności dna zbiornika}

W typowych zbiornikach paliwowych użytkowanych w kraju dno wykonywane było zwykle jako jednościankowe przy czym jego szczelność kontrolowano poprzez rurki drenarskie położone poniżej (Rys. 2). Wyciek z tych rurek paliwa magazynowanego $\mathrm{w}$ zbiorniku sygnalizował wystąpienie nieszczelności. Jednakże minimalne wycieki spod zbiornika w trakcie jego użytkowania były w praktyce bardzo trudne do wykrycia. Pomiary słupa paliwa przechowywanego w zbiorniku mogły w takich przypadkach mieścić się w granicach dopuszczal- 
nych ubytków naturalnych. Poza tym produkt z wycieku mógł utrzymywać się pod dnem niezauważony przez dłuższy czas i dopiero w okresie wiosennych roztopów lub jesiennych intensywnych opadów wypłynąć na powierzchnię terenu albo pokazać się w drenarskich rurkach kontrolnych.

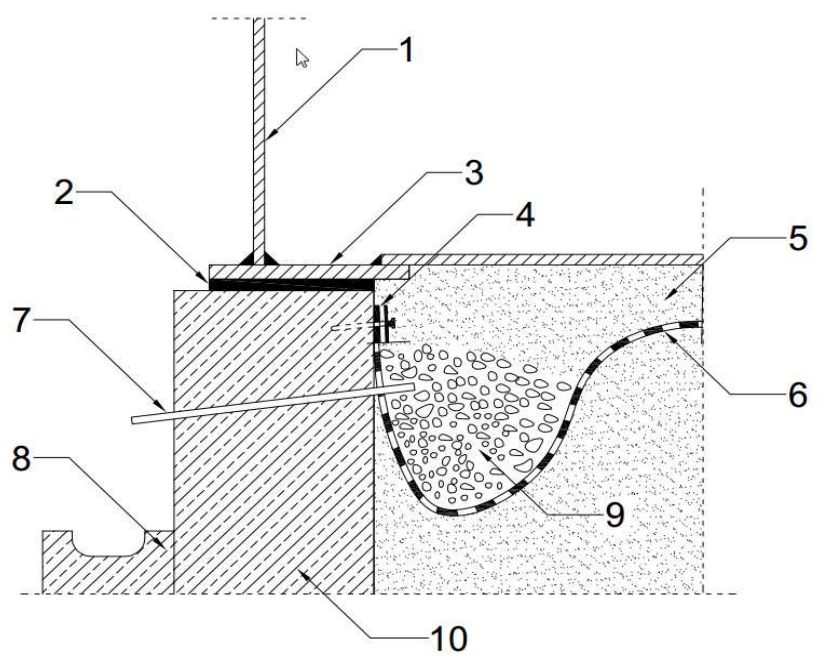

Rys. 2. Dotychczasowa kontrola szczelności jednościankowego dna zbiornika poprzez rurki drenarskie - 7. Pozostałe oznaczenia: 1 - płaszcz zbiornika, 2 - podkładka (na przykład płytka pilśniowa nasycona bitumem), 3 - pierścień obwodowy dna zbiornika, 4 - płaskownik mocujący folię izolacyjną, 5 - fundament piaskowy, 6 - folia izolacyjna, 8 - rynna kontrolna, 9 - żwirowa warstwa drenażowa, 10 - pierścieniowy fundament betonowy

Fig. 2. The tightness control commonly used hitherto for the single-layer bottom of the considered steel tank through the drainage tubes -7 . The other markings are as follows: $1-$ the steel sheet of the tank shell, 2 - a pad (for example a bitumen impregnated beaverboard plate), 3 - the steel sheet of a circumferential ring of the tank bottom, 4 - the flat steel plate fixing the insulating foil, 5 - the sand foundation, 6 - the insulating foil, 8 - a leak control channel, 9 - the gravel drainage layer, $10-$ the concrete ring foundation

Obecnie obowiązujące wymagania sformalizowane w odpowiednich warunkach technicznych [3, 4] nakładają na użytkownika zbiornika paliwowego obowiązek wyposażenia go w urządzenia lub systemy sygnalizujące powstanie wycieku oraz zabezpieczające przed przenikaniem magazynowanego produktu do gruntu, w tym w szczególności do wód powierzchniowych. Dostosowanie się do tych wymagań oznacza w praktyce konieczność modernizacji dna dotychczas użytkowanego zbiornika. Jej efektywne przeprowadzenie wiąże się z wyborem jednego z dwóch możliwych podejść konstrukcyjnych:

- budowy od wewnątrz zbiornika drugiego dna z przestrzenią monitorującą,

- podniesienia zbiornika i zainstalowania pod jego dnem geomembrany nieprzepuszczalnej dla produktów naftowych z systemem monitorowania nieszczelności. 
Decydując się na pierwsze z tych rozwiązań należy dokonać kolejnego wyboru, związanego z technologią wykonania drugiego dna. Dominują tu bowiem co najmniej dwa odrębne sposoby postępowania, zależne od tego czy drugie dno ma być wykonane jako stalowe, czy jako kompozytowe.

W przypadku wbudowywania drugiego dna stalowego na istniejącym już pojedynczym dnie zbiornika przestrzeń powstała pomiędzy górnym a dolnym dnem zostaje podzielona na sekcje po to aby w przypadku ewentualnej awarii dało się łatwiej zlokalizować uszkodzone elementy konstrukcyjne. Wadą tej technologii jest duża trudność z poprawnym wykonaniem drugiego stalowego dna jeżeli dotychczas istniejące dno jest pofałdowane, co zresztą jest powszechne w zbiornikach intensywnie i długotrwale użytkowanych (patrz Rys. 1). Przed montażem drugiego dna niezbędna jest zatem ocena stanu technicznego dna już istniejącego a następnie dokonanie jego ewentualnych napraw. Potencjalnie możliwa naprawa dna zbiornika niedługo po zamontowaniu drugiego dna stalowego może być bowiem bardzo utrudniona a przez to kosztowna. Drugą istotną wadą tego typu modernizacji jest całkowity brak wzrokowej kontroli postępu degradacji korozyjnej blach dolnego dna, pod zamontowanym górnym dnem stalowym.

Budowa drugiego dna wykonanego z kompozytu wiąże się z wytworzeniem na dotychczas istniejącym stalowym dnie powłoki z przestrzenią monitorującą, wykonanej na ogół z kompozytu wielowarstwowego lub hybrydowego, czyli na przykład z kompozytu aluminiowo - żywicznego. W przypadku zastosowania kompozytu wielowarstwowego jego dolne warstwy (tak zwane warstwy strukturalne) wykonane są z epoksydów nieprzewodzących o oporze upływu $R_{u}$ rzędu $10^{14} \Omega$. Przestrzeń monitorowaną przy tego rodzaju modernizacji uzyskuje się dzięki zastosowaniu laminatu przestrzennego, przewodność elektrostatyczną natomiast dzięki nałożeniu na górną warstwę laminatu okładziny przewodzącej o oporze $R_{u} \leq 10^{1} \Omega$ i grubości $300 \div 500 \mu \mathrm{m}$ oraz wykorzystaniu taśm węglowych stanowiących dodatkowe ścieżki przewodzące. W przypadku konstruowania drugiego dna z kompozytu aluminiowo - żywicznego przestrzeń monitorowana powstaje pomiędzy dotychczas istniejącym dnem stalowym a nową powłoką wykonaną z cienkich klejonych blach aluminiowych. Ładunki elektrostatyczne ze zbiornika odprowadzane są poprzez tę powłokę.

Istotnym problemem przy modernizacji zbiornika $\mathrm{z}$ wykorzystaniem kompozytu jest zapewnienie jego współpracy z dotychczasową konstrukcją stalową. Pomimo niewątpliwego postępu w technologii laminowania, w tym w szczególności poprawy charakterystyk fizycznych i wytrzymałościowych kompozytów stosowanych w praktyce, nadal stosunkowo często odnotowywane są awarie manifestujące się pęknięciami lub lokalnym odspojeniem laminatu (Rys. 3). Stalowe dno pracuje bowiem w czasie eksploatacji pod wpływem zmieniającej się wysokości słupa cieczy magazynowanej w zbiorniku. Przy napełnianiu blachy dna przemieszczają się do dołu, natomiast przy opróżnianiu stopniowo powracają do położenia nadanego im podczas montażu. Tego typu zmiany przy istotnej różnicy w odkształcalności stali i nałożonego na nią laminatu dość szyb- 
ko skutkują rozwarstwieniem (delaminacją) zmodernizowanej powłoki, co łączy się z koniecznością jej remontu. Często jednak sama naprawa powłoki laminatu bez uzupełnienia podsypki piaskowej pod dnem zbiornika nie gwarantuje powodzenia przeprowadzonych prac. Szerzej o problemach związanych z eksploatacją zbiorników modernizowanych metodą laminacji autorzy niniejszej pracy piszą w artykule [5].

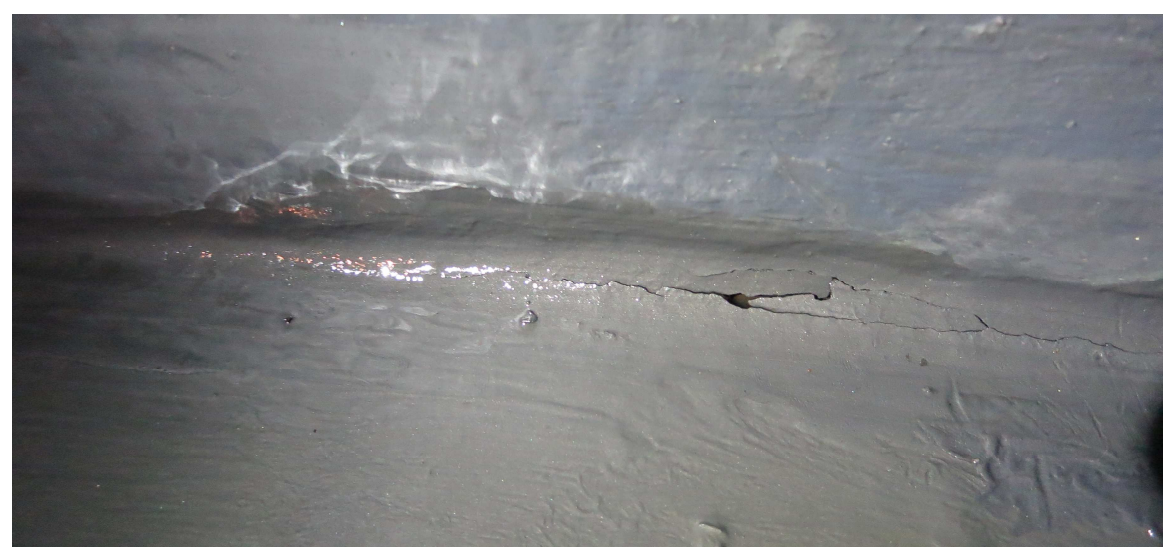

Rys. 3. Pękniecie warstwy laminatu na styku pomiędzy płaszczem i dnem zbiornika (zdjęcie J. Siudut)

Fig. 3. Crack of the laminate layer at the interface between the shell and the bottom of the tank (photo - J. Siudut)

Podstawowym zadaniem drugiego dna wykonanego z kompozytu jest zapewnienie szczelności zmodernizowanego zbiornika. Gwarancję szczelności uzyskuje się w tym przypadku stosując typową technologię polegającą na wyciągnięciu warstwy laminatu na dolną blachę płaszcza na wysokość około $1 \mathrm{~m}$ (Rys. 4a). Rozwiązanie takie uniemożliwia jednak monitorowanie stanu zachowania spoiny pachwinowej łączącej dno z płaszczem zmodernizowanego w ten sposób zbiornika. Wady tej pozbawione jest rozwiązanie alternatywne (Rys. 4b), w którym spoina ta chroniona jest warstwą przeźroczystej żywicy epoksydowej stanowiącej równocześnie niejako obramowanie zabezpieczające brzeg laminowanego dna. Oczywiście, zastosowanie takiego podejścia będzie skuteczne tylko wtedy gdy zachowa się odpowiedni poziom wykonania prac remontowych, jest ono bowiem bardzo czułe na wszelkiego rodzaju niedokładności, a zwłaszcza na ewentualne uszkodzenia mechaniczne. Dlatego warto rozważyć, czy zysk polegający na zapewnieniu dostępu do wizualnego oglądu spoiny niewątpliwie ważnej dla pracy całego zbiornika rekompensuje w tym przypadku chyba jednak dość znacznie zwiększone ryzyko zniszczenia warstwy laminatu, skutkującego potencjalną utratą jej szczelności, zwłaszcza na brzegach gdzie nie wydaje się ona zabezpieczona tak dobrze jak to ma miejsce przy tradycyjnej technologii naprawy. 
a)

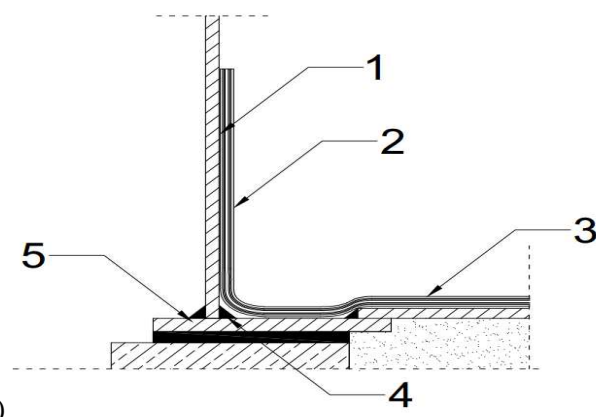

35

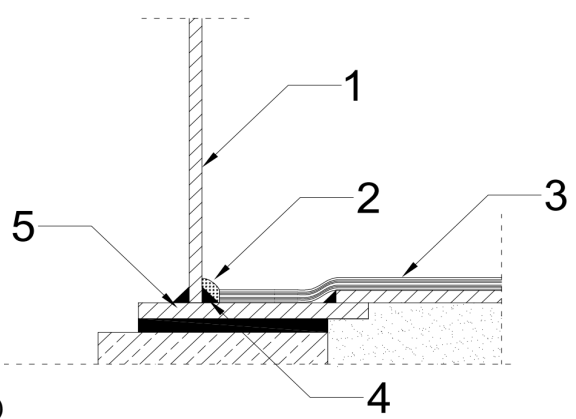

Rys. 4 Alternatywne rozwiązania brzegu kompozytowego dna zbiornika: a) rozwiązanie tradycyjne $\mathrm{z}$ warstwą laminatu wyciągniętą na dolną blachę powłoki zbiornika na wysokość $1 \mathrm{~m}$, b) rozwiązanie umożliwiające monitorowanie stanu zachowania spoiny pachwinowej łączącej stalowe dno z płaszczem zbiornika. Oznaczenia: 1 - płaszcz zbiornika, 2 - zabezpieczenie brzegu laminatu, w tym: na lewym rysunku - wywinięcie warstwy laminatu, na prawym rysunku przeźroczysta żywica epoksydowa przykrywająca spoinę, 3 - laminat pokrywający dno zmodernizowanego zbiornika, 4 - spoina pachwinowa, 5 - pierścień obrzeżny

Fig. 4. Alternative solutions for the edge of the composite bottom of the tank: a) conventional solution with the laminate layer stretched over the lowest sheet of the tank shell at the height of $1 \mathrm{~m}, \mathrm{~b})$ solution enabling monitoring of the technical condition of a fillet weld connecting the steel bottom and the shell of the tank. Markings: 1 - tank shell, 2 - protection of the edge of the laminate, including: on the left figure - flanging of the laminate layer, on the right figure: transparent epoxy resin covering the weld, 3 - laminate covering the bottom of the modernised tank, 4 - fillet weld, 5 - peripheral ring

W sytuacji gdy doszczelnienie dna wymaga dodatkowo wykonania na gruncie pod nim nieprzepuszczalnej dla produktów naftowych geomembrany wraz z odpowiednim systemem monitorowania nieszczelności zalecanym sposobem postępowania jest podniesienie całego zbiornika. Podnoszenie zbiornika ważącego niejednokrotnie kilkaset ton odbywa się przy pomocy odpowiednich siłowników. Technologia ta jest zresztą znana i stosowana od wielu lat. Możliwe są tu dwa podejścia. Zbiorniki o mniejszej masie podnoszone są na ogół w całości, natomiast w przypadku zbiorników większych często podnosi się samą powłokę zbiornika po jej odcięciu od dna. Geomembrana wykonywana jest z reguły z termoplastów lub elastomerów. Ważne aby były to materiały odporne na rozrywanie przy wydłużeniu dochodzącym nawet do $1000 \%$. Z geomembrany wyprowadza się następnie system monitorowania ewentualnych nieszczelności dna. Sama geomebrana ma $\mathrm{w}$ tym systemie powstrzymać potencjalny wyciek magazynowanego paliwa natomiast automatycznie wygenerowany sygnał alarmowy pozwolić na szybkie podjęcie działań zapobiegawczych. Niewątpliwą zaletą takiego sposobu modernizacji jest umożliwienie wykonania naprawy fundamentu zbiornika. Możliwa staje się również całkowita wymiana dna, a zatem także uzupełnienie podsypki i usunięcie innych przyczyn jego nierównomiernego osiadania. 
Tematyka planowania remontów i modernizacji zbiorników stalowych z uwzględnieniem sposobów ochrony środowiska przed wyciekami paliwa przez nieszczelne dno została przedstawiona w sposób kompleksowy w pracach [6] i [7].

\section{Dostosowanie stalowego zbiornika $\mathrm{z}$ dachem pływającym do magazynowania paliwa lotniczego typu JET}

Paliwo lotnicze typu JET $\mathrm{z}$ reguły magazynowane jest $\mathrm{w}$ zbiornikach $\mathrm{z}$ dachem stałym. Dach stały pozwala bowiem praktycznie wyeliminować ryzyko pojawienia się $\mathrm{w}$ przechowywanym produkcie wody pochodzącej $\mathrm{z}$ opadów atmosferycznych. Trzeba podkreślić, że czystość paliwa warunkuje niezawodną pracę silników samolotu. W zbiornikach $\mathrm{z}$ dachem pływającym nawet przy zastosowaniu najlepszych z obecnie znanych uszczelnień całkowite wyeliminowanie obecności wody z opadów nie jest możliwe. Jeżeli zatem w istniejącej bazie paliwowej planuje się zmianę sposobu użytkowania istniejących już stalowych zbiorników z dachem pływającym, taką aby dostosować je do przechowywania paliwa lotniczego typu JET, to jedynym zalecanym rozwiązaniem konstrukcyjnym jest przebudowa dotychczasowego dachu pływającego i nadbudowanie nad nim lekkiej kopuły aluminiowej. Najprostszym podejściem jest tu zatem kolejno: likwidacja schodów prowadzących wcześniej na dach pływający, dostosowanie istniejącego dachu pływającego do pracy w charakterze wewnętrznego ruchomego dachu i w końcu montaż nowego dachu zewnętrznego. Jak dotąd modernizowano w ten sposób w kraju zbiorniki o pojemności $2000 \mathrm{~m}^{3}$ lub $5000 \mathrm{~m}^{3}$ (Rys. 5). Wymagania eksploatacyjne dotyczące zbiorników pracujących w takiej konfiguracji nie są jednak w krajowych przepisach $[8,9]$ w żaden sposób wyspecyfikowane, co niepotrzebnie daje użytkownikowi bazy paliwowej pole do opracowywania swoistych dla danych warunków lokalnych ale nie zawsze bezpiecznych i do końca sprawdzonych rozwiązań. Pozostaje zatem oparcie się na szczegółowych wytycznych sformalizowanych przepisami opublikowanymi w innych krajach, w tym w szczególności na normach: API 650 [10] w zakresie projektowania i użytkowania oraz NFPA 11 [11] w zakresie ochrony przeciwpożarowej. Zgodnie z nimi stała kopuła aluminiowa projektowana nad zbiornikiem powinna być samonośna i oprócz obciążeń klimatycznych (śnieg, wiatr) przenosić obciążenie $p \leq 113 \mathrm{~kg} / \mathrm{m}^{2}$ (dotyczy to również podestu), co odpowiada masie pojedynczego pracownika z narzędziami rozłożonej na jeden metr kwadratowy poszycia kopuły. Poza tym zalegający na kopule śnieg może powodować ugięcie paneli jej poszycia do kąta $1,98^{\circ}$, co w praktyce, w przypadku największych blach, daje ugięcie wynoszące około $45 \mathrm{~mm}$ w stosunku do pierwotnego położenia panelu zaraz po montażu. Śnieg należy okresowo usuwać, nie tylko z samego poszycia kopuły ale i z podestów obsługowych, zwłaszcza wtedy gdy ich obciążenie przekracza wartość $s=75 \mathrm{~kg} / \mathrm{m}^{2}$, co odpowiada zaleganiu $15 \mathrm{~cm}$ mokrego śniegu. Dodatkowo kopuła musi być przystosowana do przeniesienia skupionego obciążenia stałego przyłożonego na jej szczycie po zamontowaniu iglicy odgromowej. 


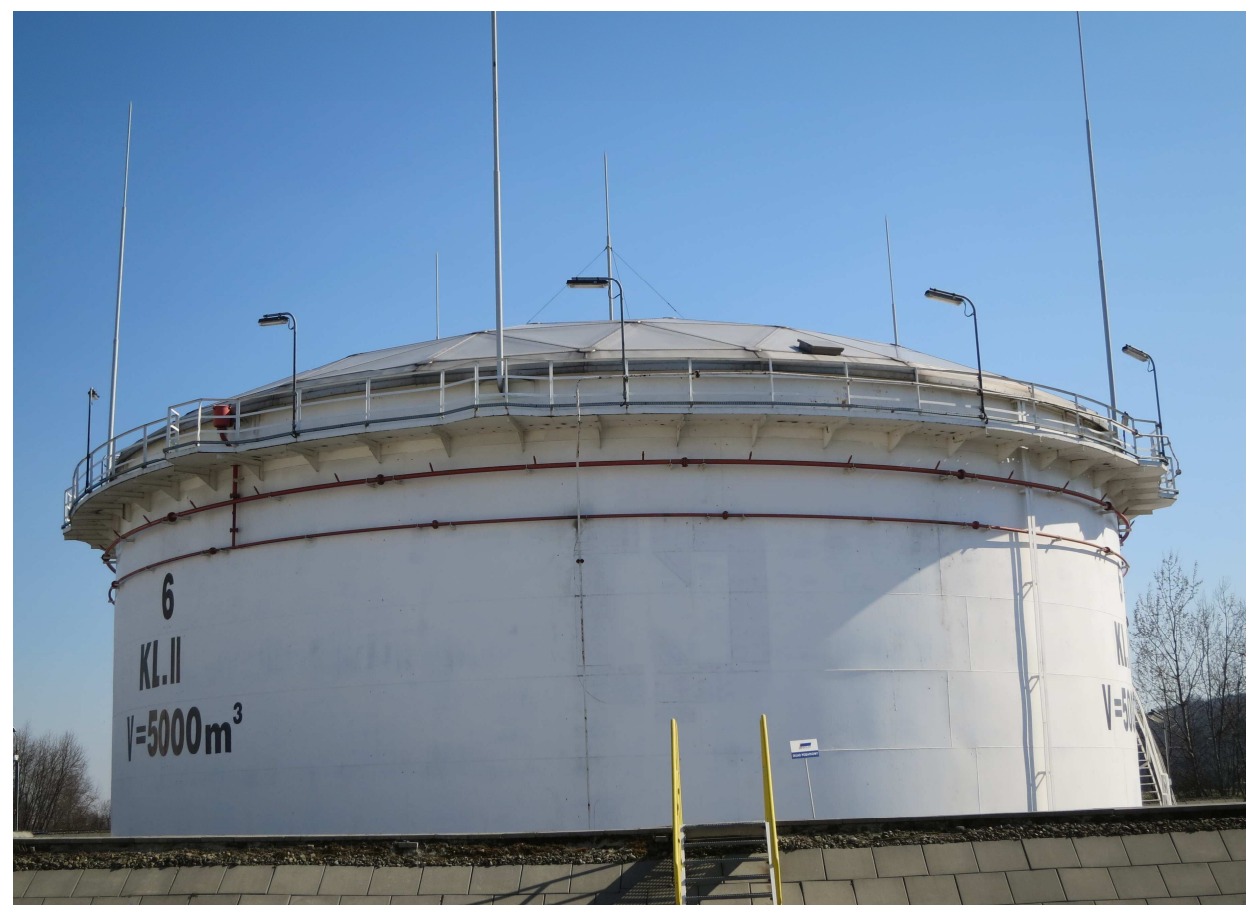

Rys. 5. Zbiornik stalowy z kopułą aluminiową i wewnętrznym dachem pływającym o pojemności $5000 \mathrm{~m}^{3}$ przystosowany do magazynowania paliwa lotniczego typu JET (zdjęcie - J. Siudut)

Fig. 5. Steel tank with an aluminium dome and an internal floating roof with a capacity of $5000 \mathrm{~m}^{3}$ adapted for the JET-type aviation fuel storage (photo - J. Siudut)

W przywołanych poprzednio przepisach nie wymaga się zapewnienia stałego dostępu na wewnętrzny dach pływający. Oczywiście, użytkownik bazy może wprowadzić tego typu wymóg w swoim zakresie. Dla dachów zewnętrznych narażonych na działanie czynników atmosferycznych (deszcz, lód, śnieg) taki dostęp jest niezbędny w celu ich ewentualnego odwodnienia lub odśnieżenia. Wizualną kontrolę stanu technicznego wewnętrznego dachu pływającego można prowadzić przez włazy w kopule aluminiowej. Dostęp do tego dachu jest wtedy możliwy jedynie w jego najwyższym (górnym) położeniu, to znaczy przy całkowitym napełnieniu zbiornika. Dla wewnętrznych dachów pływających przepisy norm $[10,11]$ nie wymagają zastosowania przerywaczy płomieni na zaworach napowietrzająco - odpowietrzających. Zawory te otwierają się jedynie podczas całkowitego opróżniania zbiornika albo na początku jego napełniania. W czasie normalnej eksploatacji, to znaczy wtedy gdy dach pływa na powierzchni magazynowanego paliwa i nie opiera się na podpierakach, zawory są zamknięte.

Konfiguracja zbiornika łącząca zastosowanie stałej kopuły aluminiowej z pozostawieniem $\mathrm{w}$ charakterze dachu wewnętrznego stalowego dachu pływa- 
jącego z pełnym kontaktem z magazynowanym paliwem jest rozwiązaniem bardzo bezpiecznym $\mathrm{z}$ uwagi na zagrożenie pożarowe. $\mathrm{Z}$ tego względu, przy spełnieniu wymogu pełnego kontaktu z cieczą, w sytuacji pożaru nie wymaga się podawania piany na całą powierzchnię dachu, a jedynie na powierzchnię jego uszczelnienia.

Montaż kopuły aluminiowej dodatkowo pociąga za sobą konieczność przebudowy dotychczas istniejących podestów na zbiorniku, dostosowania do nowej konstrukcji automatycznych systemów pomiarowych, a także wykonania nowej instalacji zraszaczowej i pianowej.

\section{Uwagi końcowe}

Zmiana sposobu użytkowania spowodowana względami logistycznymi, a często po prostu czysto ekonomicznymi, oraz wzrastające wymagania dotyczące ochrony środowiska naturalnego wymuszają na personelu wielu krajowych baz paliwowych zaplanowanie i przeprowadzenie kompleksowej modernizacji konstrukcji dotychczas istniejących stalowych zbiorników paliwowych. Wiąże się ona z podejmowaniem wielu decyzji co do wyboru efektywnej technologii prowadzenia robót remontowych, a także z poszukiwaniem takich rozwiązań, które zagwarantują odpowiednią trwałość odnowionej konstrukcji poddanej oddziaływaniom nowego typu i narażonej na specyficzne dla tych oddziaływań zagrożenia. Zadanie to jest dla użytkowników takich baz o tyle trudne, że jak dotąd brak jednoznacznie sprecyzowanych i sformalizowanych przepisów, dotyczących zarówno projektowania jak i eksploatacji takich zbiorników. Próbuje się zatem dostosować do krajowych warunków rozwiązania rekomendowane do wykorzystania w innych krajach. Pochodzą one jednak na ogół z różnych przepisów, nie zawsze wzajemnie kompatybilnych, co na pewno rodzi pewien chaos i w konsekwencji nie zawsze pozwala na realne osiągnięcie wymaganego poziomu bezpieczeństwa czy zagwarantowanie dostatecznej trwałości zmodernizowanego zbiornika. Wydaje się zatem, że należy dążyć do pewnego usystematyzowania i próby oceny rozwiązań spotykanych na tym polu w praktyce inżynierskiej. Jest to ważne także $\mathrm{z}$ tego powodu, że w kraju brak instytucji zbierającej dane $\mathrm{z}$ awarii zbiorników paliwowych spowodowanych nieprofesjonalnym przystosowaniem ich do nowej technologii czy zmianą rodzaju przechowywanego w nich paliwa. Instytucje dopuszczające nowe rozwiązania technologiczno - konstrukcyjne często nie definiują jednoznacznie gdzie i kiedy nie powinno się takich rozwiązań stosować. Kryteriów tych nie specyfikują czytelnie, niewątpliwie ze względów marketingowych, także firmy wykonawcze proponujące zastosowanie danej technologii $\mathrm{w}$ przypadku konkretnego remontu. $\mathrm{Z}$ reguły bowiem rekomendują one swoje rozwiązania jako te, które są preferowane dla każdej zaistniałej sytuacji. W tym stanie rzeczy inwestor musi opierać się jedynie na własnej wiedzy i doświadczeniu, nie ma bowiem jasnej informacji w jakich warunkach i kiedy może zastosować wybraną przez siebie technologię. 
W wielu przypadkach skutkuje to tym, że użytkownik bazy paliwowej dopiero po upływie pewnego czasu przekonuje się że pewne rozwiązania techniczne zastosowane w jego bazie się sprawdziły, natomiast inne nie.

\section{Literatura}

[1] Projekty zbiorników opracowane przez Biuro Projektów „Naftoprojekt”, Warszawa 1970.

[2] Ziółko J.: Zbiorniki metalowe na ciecze i gazy, Arkady, Warszawa, 1986.

[3] Rozporządzenie Ministra Gospodarki w sprawie warunków technicznych jakim powinny odpowiadać bazy i stacje paliw płynnych, rurociągi przesyłowe dalekosiężne do transportu ropy naftowej i produktów naftowych i ich usytuowanie (Dz. U. nr 243 z 21 listopada 2005, z późniejszymi zmianami).

[4] Rozporządzenie Ministra Gospodarki w sprawie warunków technicznych dozoru technicznego jakim powinny odpowiadać zbiorniki bezciśnieniowe i niskociśnieniowe przeznaczone do magazynowania materiałów ciekłych zapalnych (Dz. U. nr 113 z dnia 18 września 2001, z późniejszymi zmianami).

[5] Maślak M., Siudut J. : Wybrane problemy zapewnienia trwałości stalowych zbiorników na paliwa płynne modernizowanych metodą laminacji, Ochrona przed Korozją, 5s/A/2008, s. 235-240.

[6] Ziółko J.: Ochrona przed skażeniem gruntu w nowoczesnych zbiornikach stalowych na paliwa płynne, Inżynieria i Budownictwo, 10/1996.

[7] Ziółko J.: Remonty i wzmacnianie zbiorników stalowych i rurociągów dalekosiężnych, Materiały XXIII Ogólnopolskiej Konferencji „Warsztat Pracy Projektanta Konstrukcji, Szczyrk 5-8.03.2008.

[8] PN-EN 1993-4-2: 2009. Eurokod 3 - Projektowanie konstrukcji stalowych, Część 42 Zbiorniki.

[9] PN-EN 14015: 2010. Specyfikacja dotycząca projektowania i wytwarzania na miejscu zbiorników pionowych, o przekroju kołowym, z dnem płaskim, naziemnych, stalowych spawanych, na ciecze o temperaturze otoczenia i wyższej.

[10] API Standard 650. Welded tanks for oil storage. American Petroleum Institute, Twelfth Edition, March 2013.

[11] NFPA 11. Standard for low-, medium-, and high-expansion foam. National Fire Protection Association, 2010.

\section{SHAPING THE STRUCTURAL ELEMENTS IN STEEL TANKS FOR FUEL STORAGE BEING MODERNISED, RESULTING FROM CHANGES IN THE WAY OF THEIR USE AND FROM THE INCREASING ENVIRONMENTAL REQUIREMENTS}

\section{S u m m a r y}

The structural modifications necessary to comply in steel tanks for fuel storage being inservice if they are intended for further use but in the changed way of their service are presented and discussed in detail. In particular, the way how to modernise the typical existing on-the-ground 
cylindrical tank with a floating roof is considered, such as to adapt it to the storage of the JET-type aviation fuel. The preferred solution is in that case the construction of a superstructure in the form of a lightweight aluminium dome. The second issue is the sealing of the existing structure of a bottom in the tank being modernised, as required by the currently applicable environmental regulations. This can be done either by forming an additional second bottom, made of steel or of a composite, with a suitable monitoring space, or by raising the considered tank and installing under its bottom a geomembrane impermeable for petroleum products, together with the system monitoring the potential leaks.

Keywords: steel tank, modernisation, the way of use, environmental requirements, shaping the structural elements

Przestano do redakcji: $10.12 .2016 \mathrm{r}$.

Przyjęto do druku: 31.03.2017 r. 